\title{
Identification Validity Early Detection of Child Development Using Indonesian Mch Handbook
}

\author{
Indah Lutfiya ${ }^{1}$, Irwanto ${ }^{2}$, Windhu Purnomo ${ }^{3}$ \\ ${ }^{1}$ Student of Maternal and Child Health Major, Faculty of Public Health, ${ }^{2}$ Department of Child Health, Faculty \\ of Medicine, ${ }^{3}$ Department of Biostatistics and Demography, Faculty of Public Health, Airlangga University
}

\begin{abstract}
Children are inevitably essential parts of Indonesian population. Prevalence of children developmental disorders in Indonesia is still pretty high, ranging from $10-18 \%$. In fact, approximately $70 \%$ of children with developmental delays are detected without screening. Surabaya is the city with the largest number of Early Childhood Education (PAUD) institutions in East Java, Indonesia. Ministry of Health publish the latest Maternal and Child Health (MCH) Handbook containing a child development checklist. Thus, the purpose of this study is to examine the validity of MCH Handbook as a measuring tool for early detection of child development with Indonesian Pre-Screening Developmental Questionnaire (KPSP) as a gold standard among Early Childhood Education students in Surabaya city. This research was a cross sectional study using diagnostic test design. The population of the study were the children aged 3-72 months in Surabaya city. The sample were selected using multistage cluster random sampling technique, totaling of 400 children. The data were analyzed using Mc. Nemar statistic tests and Kappa Agreement tests. The results showed that there is no difference in the value of development between MCH Handbook and KPSP $(p=1,000)$. The MCH Handbook was valid with the sensitivity value of $84.5 \%$; specificity value of $96.9 \%$ and has a consistency rate of $81.9 \%$. Thus, we can conclude that $\mathrm{MCH}$ Handbook is said to be a valid early detection tool for children aged 3 months to 72 months with high agreement value and high sensitivity and specificity. It suggested to health workers to promote the importance of $\mathrm{MCH}$ Handbook utilization through social media and Primary Health Care.
\end{abstract}

Keywords: Child Development, MCH Handbook, Validity

\section{Introduction}

Indonesia is one of the countries which has the highest number of population in the world. The number of toddlers accounts for $10 \%$ of the total population in Indonesia. ${ }^{1}$ In 2015, Ministry of Health issued special regulations for health and non-health workers to monitor child growth, including monitoring of gross motor movement, fine motor movement, socialization and independence, as well as speech and language abilities. The child growth monitoring is to perform regularly from children aged 3 months to 72 months. Children with good growth and development in accordance to the age stage are expected to become healthy and productive adults as the state asset, both socially and economically. ${ }^{1,2}$

The world's developmental delay rate is around 10\% .3 In recent years, there has been about $12-16 \%$ in the
United States, $24 \%$ in Thailand, $22 \%$ in Argentina and $13-18 \%$ in Indonesia. Surabaya is the city with the highest number of Early Chilhood Education in Indonesia. All of them have a risk of developing developmental delay ${ }^{2,3}$.

The coverage of each Primary Health Service on children under five in Surabaya has decreased since 2015 from $83.58 \%$ to $82.54 \%$ in 2016 . It is in contrast to the fact that in 2010 Ministry of Health expected that $90 \%$ of children under five and preschool children be covered by early detection activities ${ }^{1}$. The unsuccessful attempt on periodic developmental screening is attributed to lack of cross-sector coordination, funding, the provision of Educational Game Equipment (APE) and the stabilization of commitments to implement policies on Stimulation, Detection and Early Intervention of Child Growth and Development (SDIDTK) ${ }^{4}$. 
Most child development disorders are unnoticed at preschool age. In fact, approximately $70 \%$ of children with developmental delays are detected without screening ${ }^{4}$. This is due to the absence of obvious symptoms of child development disorders if there is no screening in accordance to standardized instruments. A good screening tool must have the validity, reliability, sensitivity, specificity and suitability to local conditions. To know the quality of the instrument, it is required to test the validity and reliability, while to test the specificity and sensitivity, it is necessary to test the comparison of measuring instruments with gold standard ${ }^{5,6}$.

In 2015, the government published the latest Maternal Child Health/ MCH Handbook containing a child development checklist. Previously, in 2013 the government issued an Indonesian Pre-Screening DevelopmentalQuestionnaire (KPSP). KPSP should only be used by health workers ${ }^{1,2}$. To asses KPSP, someone requires special skills, unlike the MCH Handbook which can be read and used by parents as the first known child. Parents can utilize MCH Handbook as a stimulation guide and for monitoring child development. Hence, this study aims to identify the validity of $\mathrm{MCH}$ Handbook as a measuring tool of early detection of child development in Indonesia.

\section{Materials and Method}

This is a cross-sectional study with diagnostic test design. The study was conducted in Surabaya City from March to May 2018. Research respondents were 400 PAUD children aged 3 months to 72 months obtained by multistage cluster random sampling technique.

Primary data was collected by examining the child's development status using KPSP and MCH Handbook. The KPSP measurement tool is a translation of the Indonesian version of Pre-screening Developmental Questionnaire (PDQ) which contains 10 questions about the child's developmental skills, which parents must answer with yes and no answers, which only takes 1015 minutes. In this study if the answer 'Yes' less than 9 suspected the problem (suspect), if the answer "Yes " 9-10 is considered no problem (normal). While based on $\mathrm{MCH}$ Handbook, children are normal if not able to answer a maximum of 1 question posed.

Diagnostic tests are carried out by researchers to obtain the sensitivity and specificity of the $\mathrm{MCH}$
Handbook. Processing techniques and data analysis using a computer with statistical program and Mc test. Nemar and Kappa's Agreement.

\section{Findings}

Table 1 shows that the distribution of child respondents by sex is approximately the same between women $(50.8 \%)$ and men (49.2\%). The most frequently age that encountered during developmental examination was 72 months $(25.3 \%)$ while at least was 9 months $(0.5 \%)$. The children age 72 -months were easy to find at the educational level such as Kindergarten.

Table 1 shows that the majority of maternal respondents are mature and productive is about $60.8 \%$ (age 25-35 years). In terms of education level, the majority of mothers have a fairly high level of education $(83.5 \%)$. When viewed in terms of employment, the majority of mothers choose to work at home (54\%). The choice of mothers to work at home does not indicate a low level of family income. This condition is indicated by $69.5 \%$ of families fulfilled in accordance with the Regional Minimum Wage (UMR) in force in Surabaya.

Table 1: Characteristic of Respondents

\begin{tabular}{|c|c|c|}
\hline Characteristis & $\mathbf{n}$ & $\%$ \\
\hline \multicolumn{3}{|l|}{ Sex } \\
\hline Male & 197 & 49,2 \\
\hline Female & 203 & 50,8 \\
\hline \multicolumn{3}{|l|}{ Age (months) } \\
\hline 3 months & 4 & 1,0 \\
\hline 6 months & 3 & 0,8 \\
\hline 9 months & 2 & 0,5 \\
\hline 12 months & 7 & 1,8 \\
\hline 15 months & 4 & 1,0 \\
\hline 18 months & 4 & 1,0 \\
\hline 21 months & 6 & 1,5 \\
\hline 24 months & 8 & 2,0 \\
\hline 30 months & 19 & 4,8 \\
\hline 36 months & 23 & 5,8 \\
\hline 42 months & 32 & 8,0 \\
\hline 48 months & 38 & 9,5 \\
\hline 54 months & 36 & 9,0 \\
\hline 60 months & 62 & 15,5 \\
\hline 66 months & 51 & 12,8 \\
\hline 72 months & 101 & 25,3 \\
\hline
\end{tabular}


Conted...

\begin{tabular}{|c|c|c|}
\hline \multicolumn{3}{|l|}{ Mother's age (years) } \\
\hline $15-25$ & 28 & 7,0 \\
\hline $26-35$ & 243 & 60,8 \\
\hline $36-45$ & 124 & 31,0 \\
\hline $46-55$ & 5 & 1,3 \\
\hline \multicolumn{3}{|l|}{ Mother's Education } \\
\hline Primary Education & 20 & 5,0 \\
\hline Secondary Education & 46 & 11,5 \\
\hline Tertiary Education & 334 & 83,5 \\
\hline \multicolumn{3}{|l|}{ Mother's Occupation } \\
\hline Housewife & 216 & 54,0 \\
\hline Others & 184 & 46,0 \\
\hline \multicolumn{3}{|l|}{ Family Income } \\
\hline$<$ Regional Minimum Wage & 278 & 69,5 \\
\hline$\geq$ Regional Minimum Wage & 122 & 30,5 \\
\hline \multicolumn{3}{|l|}{ Number of children } \\
\hline$\leq 2$ persons & 281 & 70,3 \\
\hline$>2$ persons & 119 & 29,7 \\
\hline \multicolumn{3}{|l|}{ MCH Handbook Utilization } \\
\hline Never exploit & 67 & 16,8 \\
\hline Just read & 42 & 10,5 \\
\hline Read and filled & 291 & 72,7 \\
\hline \multicolumn{3}{|l|}{ Frequency of Posyandu Visit } \\
\hline Routine every moth & 233 & 58,3 \\
\hline $2-5$ times a year & 103 & 25,8 \\
\hline Never & 64 & 16,0 \\
\hline
\end{tabular}

Based on Table 1, some mothers have 1-2 children (70.3\%). The majority of mothers' use MCH Handbook (72.7\%). This is supported by regular visits to Posyandu $(58.3 \%)$ every month.
Table 2 shows that the majority of children are normal based on KPSP (82.3\%) and MCH Handbook (82.5\%). The prevalence suspicion of developmental disturbance is $17.8 \%$ based on KPSP and $17.5 \%$ based on $\mathrm{MCH}$ Handbook. The sensitivity value of MCH Handbook is $84.5 \%$ while the specificity is $96.9 \%$. Positive Predictive Value (PPV) calculation is high, $85.7 \%$ with Negative Predictive Value (NPV) which is also high (96.6\%).

Mc. Nemar test is used to compare MCH Handbook with gold standard (KPSP). Table 3 shows that there is no difference in the results of the examinations of the two measuring devices ( $\mathrm{sig}=1,000 ; \mathrm{p}$-value $>0.05$ ). This is indicating that the MCH Handbook can be used to assess the child's developmental status at home.

From the analysis results in table 3, we can know that the measuring tool $\mathrm{MCH}$ Handbook declared valid in measuring the child's development status. To see how much the consistency of MCH Handbook assessment, Kappa's Agreement coefficient test was performed. Table 4 shows the agreement between the two measuring devices ( $\mathrm{sig}=0,000 ; \mathrm{p}$ value $<0.05$ ). The level of agreement on the results of the examination between the two measuring instruments is high $(81.9 \%)$.

\section{Discussion}

Validity of measuring instrument test is defined as the ability of a measuring instrument to distinguish who is sick and not sick. Then this validity can be assessed with sensitivity and specificity. Based on the results of the study, the sensitivity of the MCH Handbook is seen from its ability to correctly identify children who are suspected of deviation in their development. Determination of false positive and negative will impact on health services provided ${ }^{7}$.

Tabel 2: Developmental status based on MCH Handbook and KPSP

\begin{tabular}{|c|c|c|c|c|c|c|c|}
\hline \multirow{2}{*}{\multicolumn{2}{|c|}{ Developmental Status }} & \multicolumn{4}{|c|}{ Indonesian PDQ (KPSP) } & \multirow{2}{*}{\multicolumn{2}{|c|}{ TOTAL }} \\
\hline & & \multicolumn{2}{|c|}{ Suspect } & \multicolumn{2}{|c|}{ Normal } & & \\
\hline & & $\mathbf{n}$ & $\%$ & $\mathbf{n}$ & $\%$ & $\mathbf{n}$ & $\%$ \\
\hline $\mathrm{MCH}$ & Suspect & 60 & 15,0 & 10 & 2,5 & 70 & 17,5 \\
\hline Handbook & Normal & 11 & 2,8 & 319 & 79,8 & 330 & 82,5 \\
\hline \multicolumn{2}{|c|}{ TOTAL } & 71 & 17,8 & 329 & 82,3 & 400 & 100,0 \\
\hline
\end{tabular}

Sensitivity $60 / 60+11=84,5 \% ; \mathrm{PPV}=60 / 60+10=85,7 \%$;

Spesivisity $319 / 319+10=96,9 \% ; \mathrm{NPV}=319 / 319+11=96,6 \%$ 
Tabel 3: Result of Mc. Nemar analysis

\begin{tabular}{|c|c|c|c|}
\hline Variable & Gold Standard & p-value & Information \\
\hline MCH Handbook & Indonesian PDQ (KPSP) & 1,000 & There is no difference developmental status (valid) \\
\hline
\end{tabular}

Tabel 4: Result of Kappa's Agreement analysis

\begin{tabular}{|c|c|c|c|}
\hline Variable & Gold Standard & p-value & Kappa's Agreement \\
\hline MCH Handbook & Indonesian PDQ (KPSP) & 0,000 & $81,9 \%$ \\
\hline
\end{tabular}

Calculation of sensitivity value of measuring tool MCH Handbook classified as high (84,5\%). This means that measurements using the $\mathrm{MCH}$ Handbook can represent $84.5 \%$ of cases of developmental suspicion correctly based on the gold standard. This is because the details of the questions in the MCH Handbook can represent the child's development status before further diagnosis was made. Each of the details asked has included four aspects of development as set forth in the guidance of SDIDTK ${ }^{1}$.

In Korea, Hyo Yun (2011) conducted a study on 226 children by comparing measurements issued in his country, Korean-Ages and Stages Questionnaire (K-ASQ) with Denver II. The result said that sensitivity of $76.3-90.2 \%$ was high. Based on the results of the study K-ASQ is feasible to be used to detect the child's development status in Korean territory ${ }^{8}$.

The results of the study from Glascoe and Bryne (1992) concluded the same thing. According to him, the sensitivity value generated from Denver II is high at $83 \%$. The study was conducted in 104 children ages 3 months to 72 months in five child care centers. Accurate screening will contribute to the necessary early intervention measures in children with suspected developmental impairment. Research in the Arab region conducted by Ansari and Bella (1998) revealed that the developmental pre-screening tool adopted from the DDST revision showed high sensitivity. Adoption is done by translating the points of development aspects that are asked in accordance with the ethnic and cultural conditions in Arabia ${ }^{8,9}$

Dhamayanti (2006) from Bandung city, Indonesia less agree with the results of research. The sensitivity of the measuring instrument is moderate $60 \%$. This is because the use of tools is not worth it. Similarly, Kadi (2008) who studied 85 children aged 12-14 months with a history of Low Birth Weight (LBW) in Bandung for one month in February to March 2008. The result said that sensitivity of the measuring instrument by $63 \%^{10,11}$.
Calculation of specificity value of MCH Handbook measuring instrument is high $(96,9 \%)$. This is due to the details of the question to assess the child's development in the $\mathrm{MCH}$ Handbook according to the general condition of the child in the field so that the child is able to perform and execute the instruction easily. In addition, more or less questions asked have been based on the KPSP so that the details of the question difference are not too great. The results are supported by research of Artha (2014) on 133 toddlers aged 6-60 months in Yogyakarta, Indonesia $^{10,11,12}$.

The result of research proves that $\mathrm{MCH}$ Handbook measuring instrument is valid with high agreement level $(81,9 \%)$. The value of this high agreement is supported by the result of the assessment of normal child development status resulting from KPSP and $\mathrm{MCH}$ Handbook also tend to be the same i.e. $82.3 \%$ and $82.5 \%$. The advantages of this study shows that this research was conducted on general population of children under five years' age range 3 months to 72 months, not limited to toddlers with high risk factors such as some previous research. The selection of such research subjects is more appropriate in the context of the use of both devices as a means of screening. In addition, the location of the study does not lie in slum areas that are prone to experience developmental delays due to lack of stimulation. Field observations show the items that the MCH Handbook asks are likely to be easily answered or can be done by normal children in general, so the agreement obtained tends to be high ${ }^{10,11,12}$.

The value of the agreement of a high measuring instrument is supported by Artha, et al (2014). Furthermore, research conducted in the Tehran region by Shahshahani, et al (2010) states that the Persia version of the developmental expedition screening guidelines adopted from Denver II has good validity and reliability in detecting child development status when compared with Ages and Stages Questionnaire (ASQ). The study 
was then followed up by Kazemnejad (2011) in Tehran in children aged 4-60 months. However, Marjolaine et al (2011) in his research area indicated that the agreement between ASQ and Denver II was high when compared with PEDS ${ }^{12,13,14}$.

The results of the research in the field was less agree with Kadi (2008) which resulted in the value of a moderate agreement. This is due to the different research area conditions, the number of different research subjects and the tools used are also different. His study was conducted in one place and at one age point, thus less reflecting equality at other ages ${ }^{11}$.

The disagreement on the results of the examination between commonly used screening tools further indicates the importance of good development surveillance processes. The role of clinician with experience and clinical skills becomes important to capture children who are likely or at risk of developing disorders. Some of the existing screening tools should be used with a good understanding of their respective advantages and disadvantages. Selection of any device should consider the things combined with the suitability of the existing clinical setting.

\section{Conclusion}

The MCH Handbook was valid as an early detection tool for children aged 3 months to 72 months with high agreement value $(81.9 \%)$ and high specificity sensitivity $(84.5 \%$ and $96.9 \%)$. Most children were normal according to KPSP (82.3\%) and $\mathrm{MCH}$ Handbook $(82.5 \%)$. It is recommended for health workers to promote the importance of utilizing $\mathrm{MCH}$ Handbook through social media and Primary Health Care.

Conflict of Interest: There is no conflict of interest in the study

Ethical Clearance: The study was received ethical approval from the Health Research Ethics Committee, Faculty of Public Health, Airlangga University.

\section{Source of Funding: Self}

\section{REFERENCES}

1. Kementerian Kesehatan Republik Indonesia. Pedoman Penyelenggaraan Stimulasi, Deteksi, Intervensi Dini Kembang Anak (SDIDTK). Jakarta: Bakti Husada; 2013.
2. Kementerian Kesehatan Republik Indonesia. $P M K$ No. 66 Tentang Pemantauan Tumbuh Kembang Anak. Available from: http://kespel.depkes.go.id/ uploads/imgreference/20161227113858.pdf [Accessed 30 ${ }^{\text {th }}$ September 2017].

3. Suwarba IG, Widodo DP, Handryastuti RS. Profil Klinik dan Etologi Pasien Keterlambatan Perkembangan Global di Rumah Sakit Cipto Mangun Kusumo. Sari Pediatri Journal. 2008;10(4):255-261.

4. Ariani, Yosoprawoto M. Usia Anak dan Pendidikan Ibu sebagai Faktor Risiko Gangguan Perkembangan Anak. Jurnal Kedokteran Brawijaya. 2012;27(2):118-21.

5. Glascoe FP, Robertshaw NS, Ellsworth VP. PEDS: An evidence based method for detecting and addressing developmental and behavioral problems in children. Available from: www. pedstest.com/Portals/0/files/Rogercaseexample. pdf [Accessed 29 ${ }^{\text {th }}$ December 2017].

6. Frankenburg WK, Dodds. Denver II screening manual. NewYork: Denver Developmental Materials Inc; 2004.

7. Lapau B, BirwinA. Prinsip dan Metode Epidemiologi. Depok: PT. Kharisma Putra Utama; 2017.

8. Hyoyun GA, Kwon JY. A Comparison of the Korean-Ages and Stages Questionnaires and Denver Developmental Delay Screening Test. Annals of Rehabilitation Medicine. 2011;35: 369-374. Available from: doi:10.5535/ arm.2011.35.3.369

9. Ansari SS, Bella H. Translation and Adaptation of the Revised Denver Pre Screning Developmental Questionnaire for Madinah Children, Saudi Arabia. Special Communication. Annals of Saudi Medicine. 1998;18 (1):42-46

10. Dhamayanti, M. Kuesioner Praskrining Perkembangan (KPSP) Anak. Sari Pediatri, Vol. 8, No. 1, Juni 2006: 9 - 15

11. Kadi FA, Garna H, Fadlyana E. Kesetaraan Hasil Skrining Risiko Penyimpangan Perkembangan Menurut Cara KPSP dan Denver II pada Anak Usia 12-14 Bulan dengan Berat Lahir Rendah. Sari Pediatri. 2008;10(1):29-33 
12. Artha NM, Sutomo R, Gamayanti. Kesepakatan Hasil KPSP, PEDS dan Tes Denver II untuk Skrining Perkembangan Anak Balita. Sari Pediatri. 2014;16(4):266-270.

13. Shahshahani S, Vameghi R, Azahri N, Sajedi F. Validity and Reliability Determination of Denver Developmental Screening Test-II in 0-6 Year-Olds in Tehran. Iran Journal Pediatr. 2010;20(3):313322
14. Kazemnejad, A. Comparing the Results of Developmental Screening of 4-60 Months Old Children in Tehran Using ASQ \& PDQ. Iranian Rehabilitation Journal. 2011;9(1):3-7

15. Marjolaine M., Joyce DP. Comparison of the ASQ and PEDS in Screening for Developmental Delay in Children Presenting for Primary Care. Journal of Developmental \& Behavioral Pediatrics. 2011;32(7):1-13 